\title{
UPPER BOUNDS ON MULTIPLE GENERALIZED MATHIEU SERIES
}

\author{
ŽIVORAD TOMOVSKI, Delčo LeŠKOVSKI AND TiBOR K. POGÁNY
}

Abstract. The main aim of this short note is to obtain new very general upper bounds for multiple generalized Mathieu series considering the related integral representation obtained recently by Pogány and Tomovski [?], by means of the multiple Hardy-Hilbert type integral inequality given in [?].

Mathematics subject classification (2010): Primary: 26D15, 40B05; secondary: 26B40, 33E20.

Keywords and phrases: Multiple generalized Mathieu series, generalized Hardy-Hilbert integral inequality, non-conjugated Hölder parameters.

\section{REFERENCES}

[1] I. Brnetić, M. Krnić M. And J. PeČArić, Multiple Hilbert and Hardy-Hilbert inequalities with non-conjugated parameters, Bull. Austral. Math. Soc. 71 (2005), 447-457.

[2] P. Cerone And C.T. LenARd, On integral forms of generalized Mathieu series, JIPAM J. Inequal. Pure Appl. Math. 4, 5 (2003), Art. 100.

[3] B. DRAŠČIĆ AND T.K. PogÁNY, On integral representation of the first kind Bessel function, J. Math. Anal. Appl. 308, 2 (2005), 775-780.

[4] B. Draščćć BAn, On multiple Mathieu $(\boldsymbol{a}, \boldsymbol{\lambda})$-series, Miskolc Math. Notes 11, 1 (2010), 53-62.

[5] I.S. Gradshtein And I.M. Ryzhik, Table of Integrals, Series and Products, 4.Ed. supervised by Yu. V. Geronimus and M. Yu. Tseitlin, Fizmatgiz, Moscow, 1963. (In Russian)

[6] M. KRniĆ, Ž. TOMOVS KI AND J. PEČARIĆ, Hilbert inequalities related to generalized hypergeometric functions ${ }_{m} F_{n}$, Math. Balkanica (N.S.) 22, 3-4 (2008), 307-322.

[7] É.L. Mathieu, Traité de Physique Mathématique VI-VII: Théorie de l'élasticité des corps solides, Gauthier-Villars, Paris, 1890.

[8] T.K. PogÁnY, Integral representation of a series which includes the Mathieu a-series, J. Math. Anal. Appl. 296, 1 (2004), 309-313.

[9] T.K. PogÁNY, Integral representation of Mathieu $(\mathbf{a}, \boldsymbol{\lambda})$-series, Integral Transform Spec. Funct. 16, 8 (2005), 685-689.

[10] T.K. PogÁnY And Ž. Tomovs Ki, On multiple generalized Mathieu series, Integral Tranforms Spec. Funct. 17, 4 (2006), 285-293.

[11] T.K. PogánY And Ž. Tomovs KI, Bounds improvement for alternating Mathieu type series, J. Math. Inequal. 4, 3 (2010), 315-324.

[12] T.K. Pogány, H.M. SRivastava And Ž. Tomovski, Some families of Mathieu a-series and alternating Mathieu a-series, Appl. Math. Comput. 173, 1 (2006), 69-108.

[13] H.M. SRIVASTAVA AND Ž. TOMOVSKI, Some problems and solutions involving Mathieu's series and its generalizations, JIPAM J. Inequal. Pure Appl. Math. 5, 2 (2004), Art.45.

[14] Ž. Tomovski, New double inequalities for Mathieu type series, Publikacije Elektrotehn. Fak. Ser. Mat. Univ. Beograd 15 (2004), 79-83.

[15] Ž. TOMOVSKI AND D. LEŠKOVSKI, Refinements and sharpness of some inequalities for Mathieu type series, Math. Maced. 6 (2008), 61-71.

[16] Ž. Tomovs KI AND T.K. PogÁnY, New upper bounds for Mathieu type series, Banach J. Math. Anal. 3, 2 (2008), 9-15.

[17] Ž. Tomovski And K. TRenČEvski, On an open problem of Bai-Ni Guo and Feng Qi, JIPAM J. Inequal. Pure Appl. Math. 4, 2 (2003), Art. 29. 
[18] B.-C. YANG AND T.M. RASSIAS, On the way of weight coefficients and research for the Hilbert-type inequalities, Math. Inequal. Appl. 6 (2003), 625-658. 